Harald Völkl · Florian Lang

\title{
Electrophysiology of betaine transport in isolated perfused straight proximal tubule
}

Published online: 17 February 2001

(C) Springer-Verlag 2001

Due to an unfortunate error, an incorrect version of Fig. 2B was published. The correct version is printed below.

Fig. 2A-D Influence of removing extracellular $\mathrm{Na}^{+}$and $\mathrm{Cl}^{-}$and adding $\mathrm{Ba}^{2+}$ on the depolarizing effect of betaine.

A Original tracing showing the influence of $\mathrm{Na}^{+}$removal $\left(-\mathrm{Na}^{+}, \mathrm{Na}^{+}\right.$replaced by choline). B Original tracing showing the influence of $\mathrm{Cl}^{-}$removal $\left(-\mathrm{Cl}^{-}\right.$, replaced by gluconate). C Original tracing showing the influence of $\mathrm{Ba}^{2+}$

(2 mM). D Arithmetic means \pm SEM of the depolarization induced by betaine $(10 \mathrm{mM})$ $\left(\triangle P D_{b l}\right)$ without (black columns) and with addition of $\mathrm{Ba}^{2+}\left(\mathrm{BaCl}_{2}\right)$ or removal of $\mathrm{Na}^{+}$ $\left(\mathrm{Na}^{+}\right.$-free $)$or removal of $\mathrm{Cl}^{-}$ $\left(\mathrm{Cl}^{-}\right.$free $)$. *Statistical significance between black and white columns
A

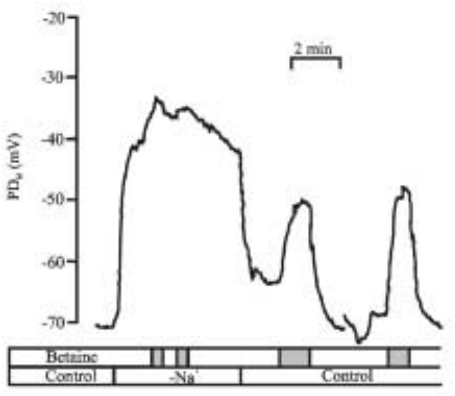

C

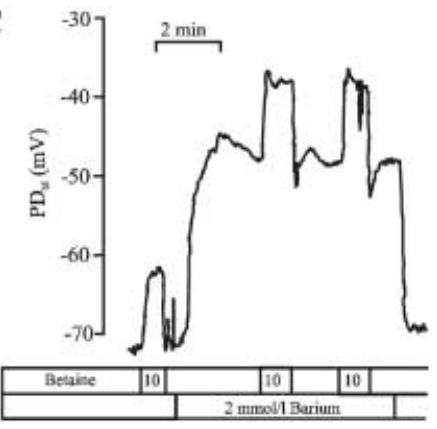

B
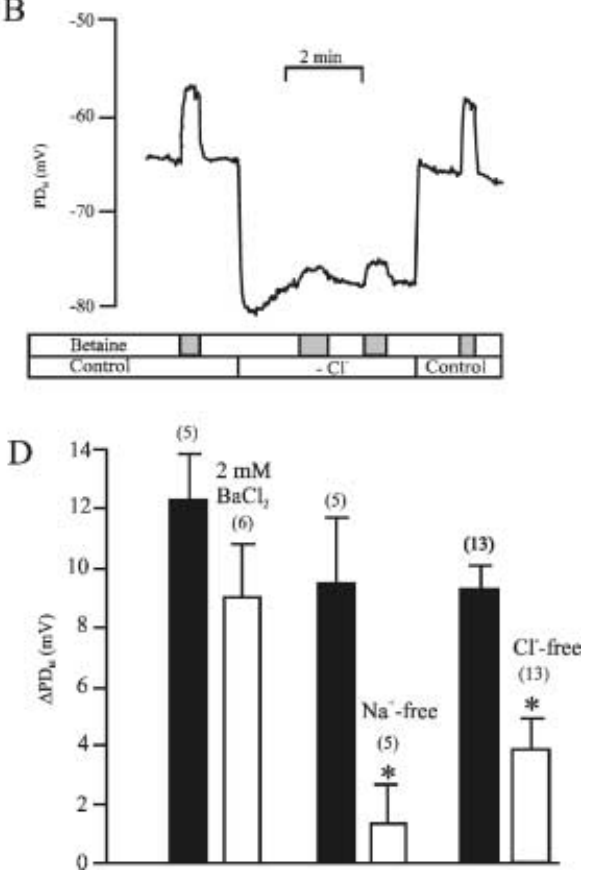

H. Völkl (『)

Institut für Physiologie, Universtität Innsbruck,

Fritz-Pregl-Strasse 3, 6010 Innsbruck, Austria

e-mail: harald.voelkl@uibk.ac.at

Fax: +43-512-5072853

F. Lang

Institut für Physiologie, Universität Tübingen, Tübingen,

Germany 